DOI https://doi.org/10.18551/rjoas.2020-11.16

\title{
PERFORMANCE OF CROSS BREEDING SUGAR CANE CLONES IN INCEPTISOL SOIL
}

\author{
Lestari $^{\star}$, Abdurrakhman, Herawati Anik, Yulaikah Sri, Supriyono \\ Indonesian Sweetener and Fiber Crops Research Institute, Malang, Indonesia \\ ${ }^{\star}$ E-mail: lestari226@gmail.com
}

\begin{abstract}
Even though ratoon sugarcane (RC) plantation takes $75 \%$ of the total area for sugar cane plantation in Indonesia, its productivity is lower than PC. One method to increase RC productivity is through crossbreeding. Objective of this research was to get superior seeds in order to increase productivity and promote sugar self-sufficiency. This research was conducted at KP. Karangploso Malang from January to December 2019. It was carried out without any trial. The data analysis method was descriptive analysis. The research materials were 165 sugar cane clones selected from 2017 crossbreeding. Observations, made before harvest, aimed at observing number, length and diameter of sugar cane stalks. The clones were grown in plot of land. The number of stalks was observed counting all stalks grown in similar grids of which minimum length was 150 centimeters and minimum stalk diameter was 15 milimeters. Ten sample plants per clone were taken for observation. The results showed eighteen sugarcane clones indicated as early-middle ripe sugar canes produced between 1.75 and 6.45 stalks/cluster or 4.36 stalks/cluster in average. The remaining 147 clones indicated as middle-slow ripe clones produced between 2.00 and 7.40 stalks/cluster or in average 4.21 stalks/cluster. Diameter of the early-middle ripe clines was between 1.77 and 3.36 centimeters (an average of 2.57 centimeters), while that of the middle-slow ripe sugar cane clones was between 1.94 and 3.76 centimeters (average of 2.69 centimeters). The early-middle ripe sugarcane clones were between 88.0 and 207.0 centimeters long, or 140.61 centimeters in average while the middle-slow ripe clones was between 48.0 and 199.0 centimeters long or 132.1 centimeters in average.
\end{abstract}

\section{KEY WORDS}

Sugar cane, production rate, clone, crossbreeding.

Increase in production, through both intensification and extensification, is a requirement for self-sufficiency in the national sugar production. Intensification is carried out in order to increase productivity, yield, and crystalized yield. One of the methods to increase sugar cane productivity is to create more robust sugar clones, which can be obtained through crossbreeding. Sugar canes, raw material for sugar production, is a strategic commodity for Indonesian government (Tarigan et al., 2015). Based on its harvest time, sugar cane in Indonesia can be categorized into three groups, namely early ripe, middle ripe and slow ripe sugar cane. Early ripe sugar cane is harvested between May and June, the beginning of sugar milling, while the middle ripe and slow ripe sugar canes are harvested from July through August, and September through October, the end of milling season, respectively. Ideal proportion of sugar cane supply for sugar mills is 30\% of early ripe sugar canes, $40 \%$ of middle ripe sugar canes, and $30 \%$ of slow ripe sugar canes. Increase of crystalized yield is represented by amount of yield.

Dry land where sugar cane is planted is dominated by Inceptisol, Vertisol, and Ultisol soil, while fertile land, for example rice field, is used to plant food crops such as corn, paddy, and soybean. Inceptisol has medium soil fertility and this type of soil is currently underutilized. Total area of Inceptisol soils is 20.75 million ha or $37.5 \%$ of the total area in Indonesia (Muyassir et al., 2012). Kadarwati (2016) described that sugar cane can be grown in Inceptisol, Alfisol, and Vertisol soil. These soil types need specific sugar clones in order to obtain high crystalized yield. Objective of this study was to find out performance of sugarcane crossbred clones in 2017. 


\section{MATERIALS AND METHODS OF RESEARCH}

This study was carried out in Experimental station of Karangploso Malang between January and December 2019. The materials were 165 selected clones from 2017 crossbreeding. The instruments were measurement tapes, scales, calipers, hand refractometers, and other instruments.

165 clones were grown in an individual plot of land. Each plot consisted of two grids of which length was 5 meters each. Distance between each grid was 110 centimeters. Bud set was grown in nursery. The authors selected uniform 1.5 months bud sets and they were grown in a grid. Distance between grids was 50 centimeters and therefore, total sets per plot were 20 bud sets.

Dosage of fertilization was $160 \mathrm{kgs}$ of $\mathrm{N}+70 \mathrm{kgs}$ of $\mathrm{P}_{2} \mathrm{O}_{5}+60 \mathrm{kgs}$ of $\mathrm{K}_{2} \mathrm{O}$ per hat that equaled to $800 \mathrm{kgs}$ of $\mathrm{ZA}+200 \mathrm{kgs}$ of SP36 + $100 \mathrm{kgs}$ of $\mathrm{KCl}$ per ha. SP36 fertilizer was administered together with soil cultivation. ZA fertilizer was administered twice; the first was $300 \mathrm{kgs}$ of ZA fertilizer two weeks after the seeds were planted and the second was $500 \mathrm{kgs}$ of the fertilizer two months after the first administration. $100 \mathrm{kgs}$ of $\mathrm{KCl}$ fertilizer was also administered during the second ZA fertilization. Other treatments included weeding, and pest and disease control.

Observations were carried out prior to harvest by measuring number, length, and diameter of sugar cane stalks. Number of stalks referred to all stalks of which minimum length was 150 centimeters and minimum diameter was $15 \mathrm{~mm}$. Length and diameter of the stalks were measured based on ten samples of plants per clone. The plant stalks and yield were weighed during harvest. On ten samples of the sugar cane samples were weighed. 6 out of the sample were pressed in order to measure their yields.

Data analysis method was descriptive analysis. Selected clones were ones that met established number of stalks per meter of the grid, and stalk weight as well as high productivity and yield.

\section{RESULTS AND DISCUSSION}

Based on budding time, between the time the seeds were planted and 10 months after that, the clones can be divided into two groups, 18 budding clones and 147 non-budding clones. Table 1 showed the clones numbering and into which groups each of them belonged. Budding clones were classified as early-middle ripe sugar clones, while non-budding clones were middle-slow ripe sugar canes.

Table 1 - 2017 Sugar Cane Clones and Their Categories

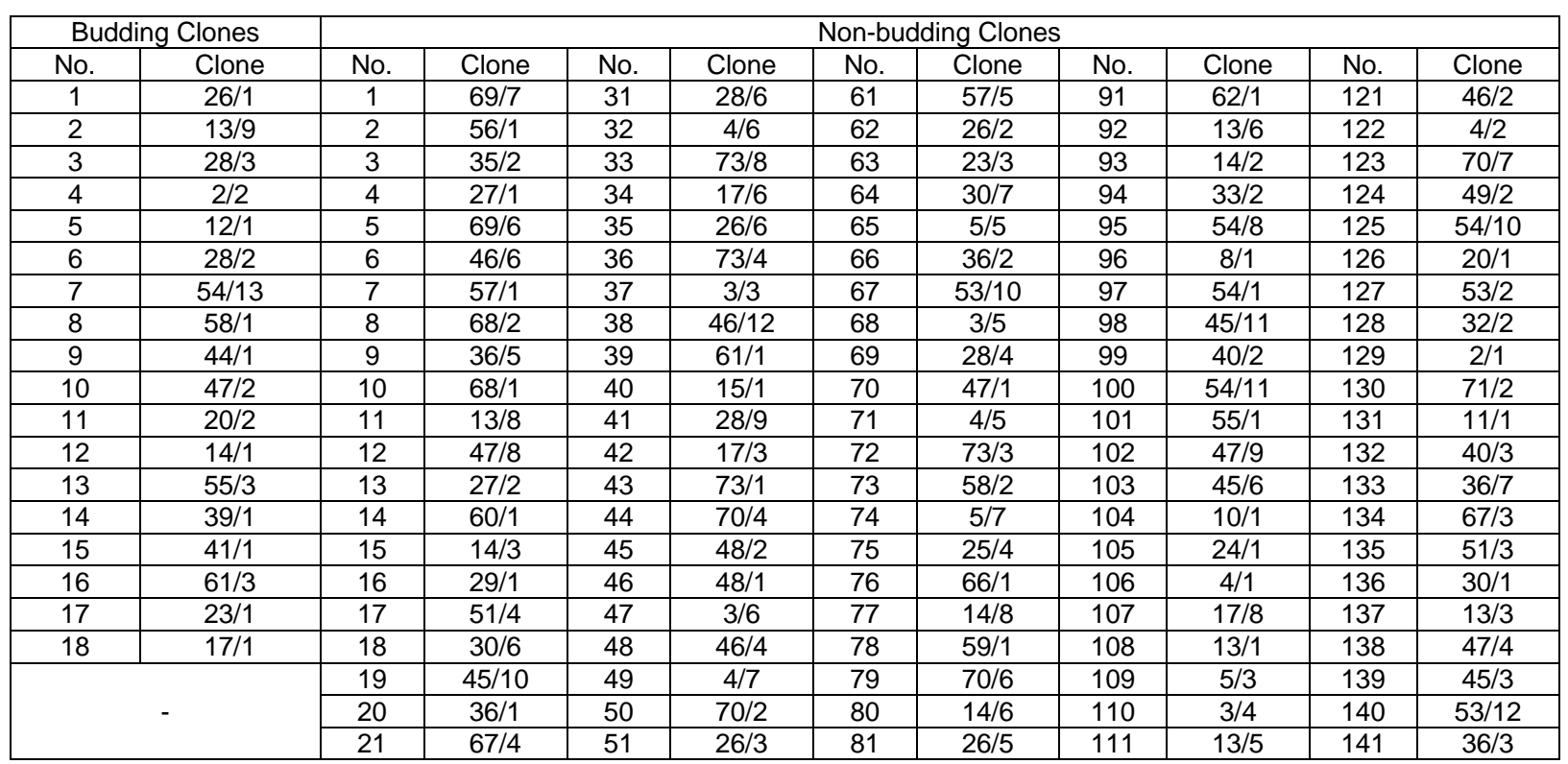




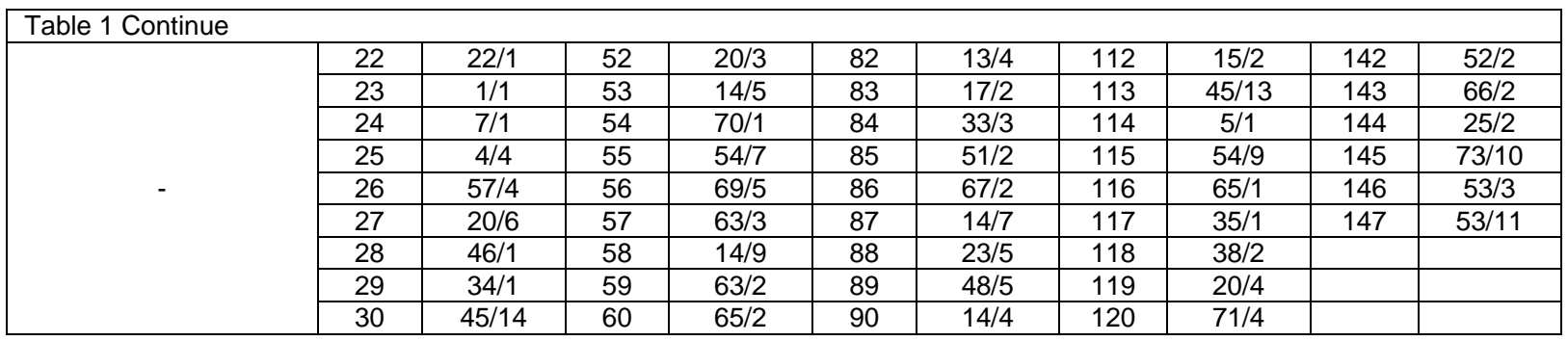

The early-middle ripe sugar cane clones produced between 1.75 and 6.45 stalks/ cluster, or approximately 4.36 stalks/ cluster (Figure 1a). On the other hand, the middle-slow ripe sugar cane clones produced between 2.00 and 7.40 stalks/ clone or approximately 4.21 stalks/clone (Figure 1b). The distance between plants in the grid was 50 centimeters and as the result, stalks produced was twice more than those per cluster. With an assumption that expected number of stalks per $m$ of the grid was 9.0 , the experiments resulted in 10 earlymiddle ripe sugar cane clones (2/2, 14/1, 13/9, 28/3, 12/1, 44/1, 55/3, 47/2, 26/1 dan 28/2) and 34 middle-slow ripe clones.
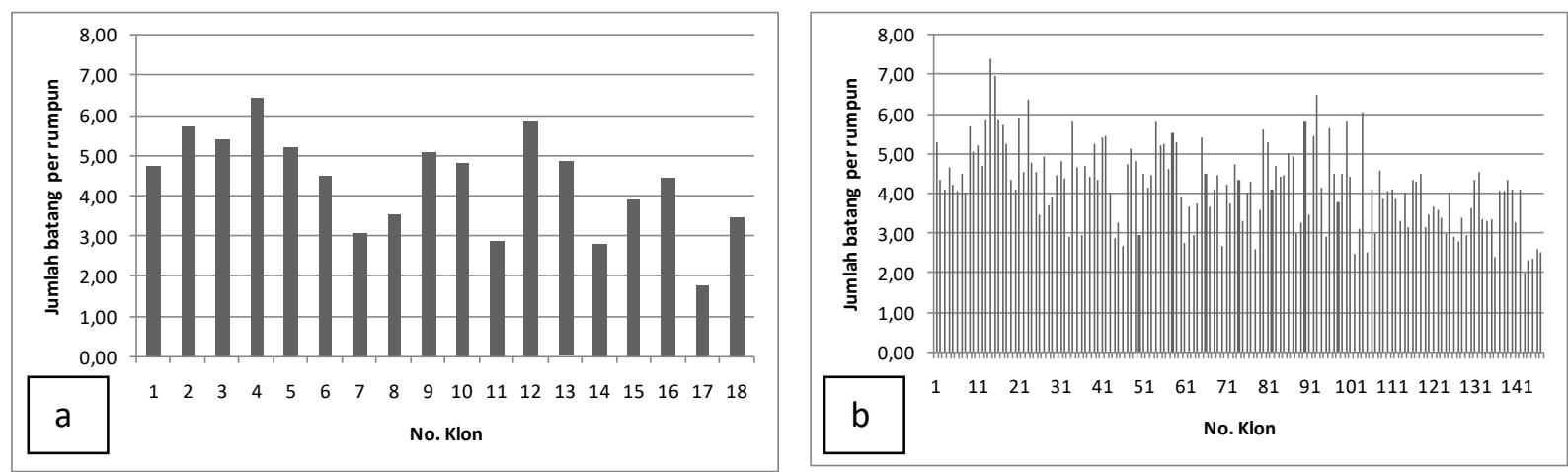

Figure 1 - Sugar Cane Stalk per Cluster (a) early-middle ripe sugar cane clones, and (b) middle-slow ripe sugar cane clones

Wang et al (2013) stated that number of stalks per cluster was determined based on plant's ability to form tillers and food supply affecting their growth. Plant genetics influenced its ability to form tillers, while amount of carbohydrates affected ability of plant to supply food. Limited amount of carbohydrates resulted in fewer stalks per meter of the grids. Under the same condition, amount of carbohydrates for plant growth was determined by plant genetics. Shukla (2007) and Dashora (2012)'s studies showed that sugar cane genetics affected different number of stalks produced.

Streck et al. (2010) explained that length of plant stalk and its diameter represented accumulated carbohydrate starting from the time when the plant was grown until the plant was harvested. As an addition, Silva et al. (2013) argued that the higher amount of carbohydrate accumulated during the period, the higher the plant stalk and the larger its diameter were. Jones et al. (2011) and Marin et al. (2011) postulated that in a long period of time, accumulated carbohydrate for growth was determined by amount of carbohydrates available for daily growth. Daily accumulation of carbohydrate was obtained from photosynthesis result subtracted by respiration (Streck et al., 2010). According to Stirbert et al. (2014), rate of photosynthesis was affected by interaction, plant genetics and environment where it grew. In a homogenous condition, genetics influenced rate of photosynthesis (Zhao et al., 2015). Therefore, plant genetics affected length and diameter of plant stalk grown in homogenous environment.

The early-middle ripe sugar cane clones were between 88.0 and 207.0 centimeters long or 140.61 centimeters in average (Figure 2a). On the other hand, the middle-slow ripe clones were between 48.0 and 199.0 centimeters long or 132.1 centimeters in average (Figure $2 \mathrm{~b}$ ). With the minimum length of sugar cane stalk of 150 centimeters, there were 5 
early-middle ripe sugar cane clones (20/2, 26/1, 28/2, 28/3 and 55/3) and 40 middle-slow ripe clones that met the criterion. Rahman et al. (2008)'s study revealed that sugar cane genetics influenced length of the plant.
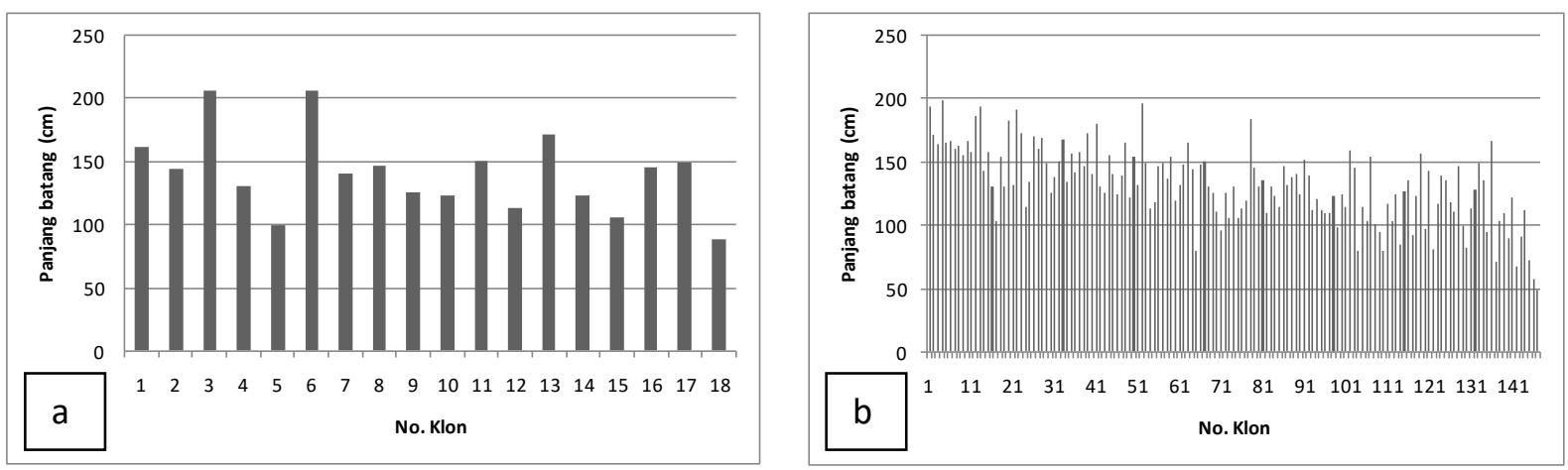

Figure 2 - Length of Sugar Cane Stalks (a) early-middle ripe sugar cane clones, and (b) middle-slow ripe sugar cane clones

Diameter of the early-middle ripe sugar clones was between 1.77 and 3.36 centimeters or 2.57 centimeters in average (Figure 3a), while that of the middle-slow ripe sugar cane clones was between 1.94-3.76 centimeters or 2.69 centimeters in average (Figure 3b). With the minimum required diameter of 2.00 centimeters, the majority of the sugar cane clones met this criterion except 55/3 and 66/3 of the early-middle ripe clones, and 13/6, 40/3, 45/3, $47 / 4$ and 54/11 for middle-slow ripe clones. Islam et al. (2011) showed that different genetics contributed in different sugar cane stalk diameter.
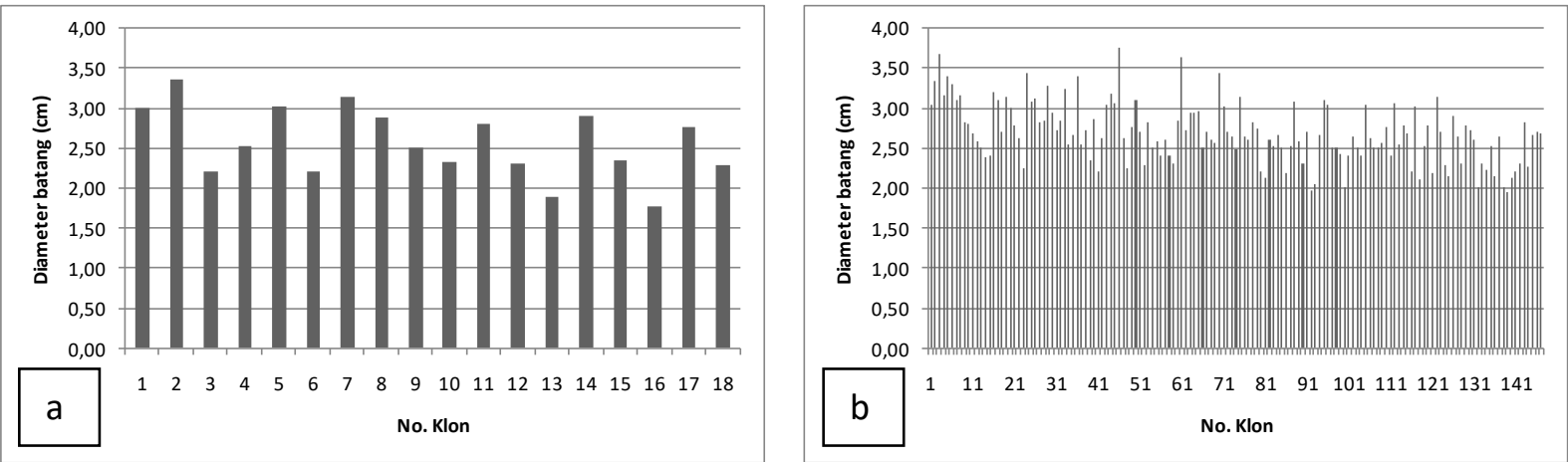

Figure 3 - Stalk Diameter (a) early-middle ripe sugar cane clones, and (b) middle-slow ripe sugar cane clones

Yong et al. (2019) stated that weight of sugar cane stalk is accumulation of carbohydrates available for stalk growth bobot during vegetarif phase and stored carbohydrate in generative phase. Genetics of the plant influenced both types of carbohydrates. As the result, the stalk weight varied a lot. Weight of the early-middle ripe sugar cane clone stalks was between 0.40 and 1.43 kilograms/stalk or 0.83 kilograms in average (Figure 4a). The early-middle ripe sugar cane clones of which weight exceeded 1.00 kilogram/stalk were 26/1, 13/9,54/13,58/1, 20/2 and 23/1. As an addition, weight of the middle-slow ripe sugar cane clone stalks was between 0.30 and 1.96 kilograms/stalk or 0.86 kilograms/stalk in average (Figure 4b). There were 39 middle-slow ripe sugar cane clones of which weight exceeded $1.00 \mathrm{~kg} / \mathrm{stalk}$. Chohan et al. (2014) revealed that genetics have contribution toward different stalk weight.

Stalk length and stalk diameter are growth components that determine stalk weight (Chohan et al., 2014 and Sajjad et al., 2014). This study revealed correlation between stalk weight (Bbat) and length (Pbat) and stalk diameter (Dbat) and the correlation resulted in an equation, Bbat $=0.6791$ Pbat +1.2708 Dbat -0.9035 with coefficient of correlation $(r)$ of 
0.986. It means that length and diameter of sugarcane stalks influenced $98.6 \%$ of the weight. Degrees of influence of these two components toward stalk weight were $43.2 \%$ for stalk length and $55.4 \%$ for stalk diameter. In other words, method to increase weight of the sugarcane stalks was to increase its diameter.
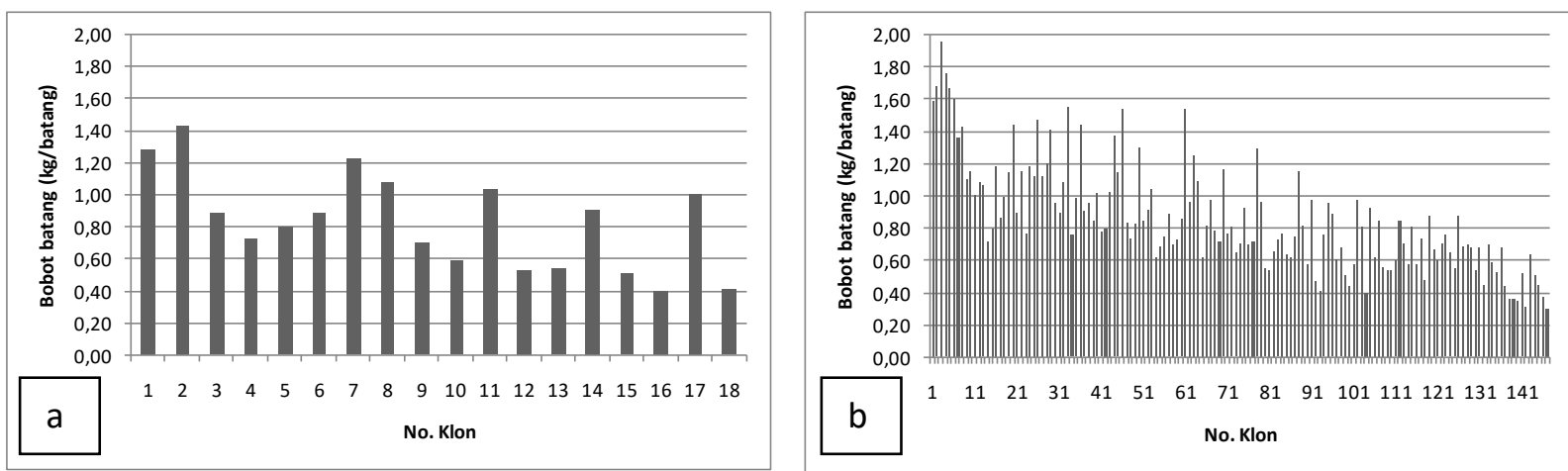

Figure 4 - Stalk weight (a) early-middle ripe sugar cane clones, and (b) middle-slow ripe sugar cane clones

Sugarcane productivity refers to total weight of harvested sugarcane stalks per area and it is one of the components contributing to crystal yield (Khalid et al., 2015). Productivity of the early-middle ripe clones was between 1.41 and $8.24 \mathrm{~kg} /$ cluster (Figure 5a), while that of the medium-slow ripe clones were between 0.76 and $8.42 \mathrm{~kg} / \mathrm{cluster}$ or 3.58 kilograms/cluster in average (Figure $5 \mathrm{~b}$ ). With an assumption that minimum sugarcane productivity of 70 t/ha or equivalent to 4.32 kilograms/cluster, the clones that met this assumption were 17/2/2, 17/13/9,17/26/1 and 17/28/, all of those were early-medium ripe clones, and 37 medium-slow ripe clones. Soomro et al. (2012) stated that genetics influenced sugar cane productivity.
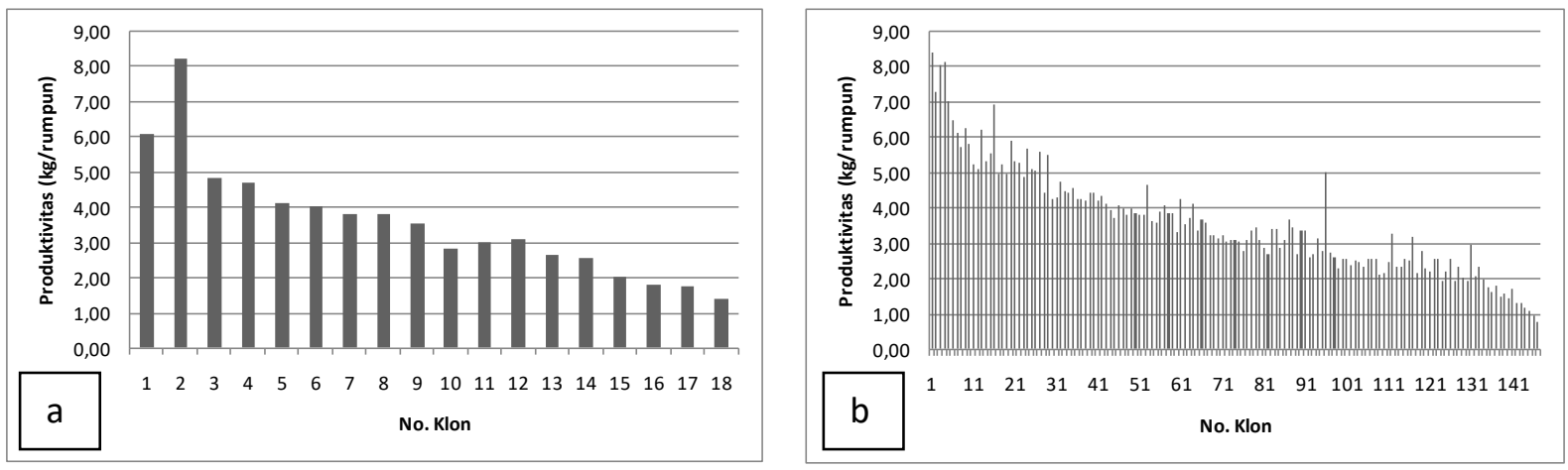

Figure 5 - Productivity (a) early-middle ripe sugar cane clones, and (b) middle-slow ripe sugar cane clones

Stem weight and number of stalks are two components contributing to sugarcane productivity (Kumar et al., 2012 and Patel et al., 2014). This study illustrated relationship between sugarcane productivity (Protas), number of harvested stalks (Jbat) and sugarcane weight (BBat) and this correlation is represented into an equation, namely Protas $=0.9426$ Bbat $+0.7246 \mathrm{Jbat}-0.40004$ with coefficient of correlation $(r)$ of 0.979 . It means that weight and number of stalks had $97.9 \%$ influence towards sugarcane productivity. Degrees of influence weight and number of stalks has toward sugarcane productivity were $62.0 \%$ for weight and $35.9 \%$ for number of stalks. In conclusion, method to improve sugar cane productivity is to improve increase sugar cane stalk weight.

Inoue et al. (2009) proposed that yield reflects how much sucrose harvested sugarcane stalk has; the higher the yield, the higher the sucrose content is. Sucrose in sugarcane stalks is accumulation of stored carbohydrates from the early generative phase ( 9 months after 
planting) until harvest. Stored carbohydrates photosynthate residue from respiration process. Length of tim generative phase and amount of stored carbohydrates for each plant genetic varies greatly. Yield produced by the early-middle ripe clones was between 6.62 and $11.37 \%$ or $9.18 \%$ in average (Figure $6 \mathrm{a}$ ), while that of the middle to slow ripe sugarcane clones was between 5.20 and $11.37 \%$ or $9.54 \%$ in average (Figure $6 \mathrm{~b}$ ). With assumption that the lowest yield was $9.0 \%$, the early-middle sugar cane clones that met the criterion were $17 / 1,20 / 2$, $26 / 1,39 / 1,44 / 1,47 / 2,54 / 13$. On the other hand, there were 109 middle-slow ripe clones that met the aforementioned criterion. Schultz et al. (2017) showed genetics play a role in sugar cane yield.
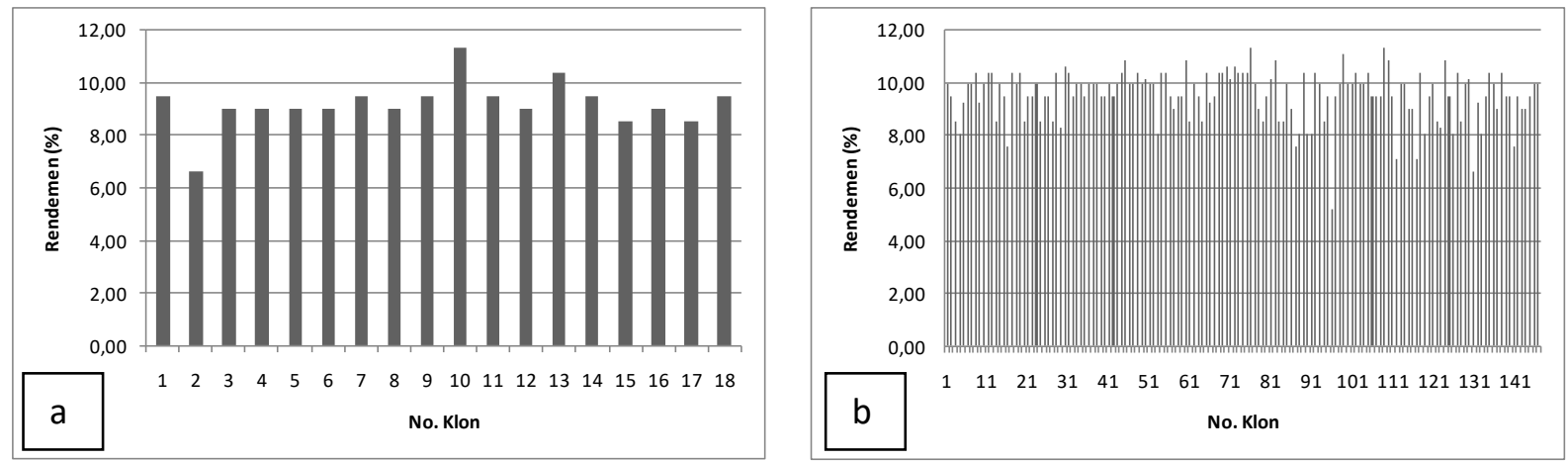

Figure 5 - Yield (a) early-middle ripe sugar cane clones, and (b) middle-slow ripe sugar cane clones

Crystal yield produced from the early-middle ripe clones was between 0.133 and 0.577 kilograms/cluster or 0.320 kilograms/cluster in average (Figure 7a), while that produced from the medium-slow ripe sugarcane clones was between 0.076 and 0.837 kilograms/cluster or 0.339 kilograms/cluster in average (Figure 7b). With assumption that minimum weight of crystal yield was 0.389 kilograms/cluster, 4 early-middle ripe sugar clones (2/2, 13/9, 26/1 and $28 / 3$, and 50 middle-slow ripe sugarcane clones met the criterion. Soomro et al. (2012)'s study genetics affected crystalized yield the sugarcane clones produced.
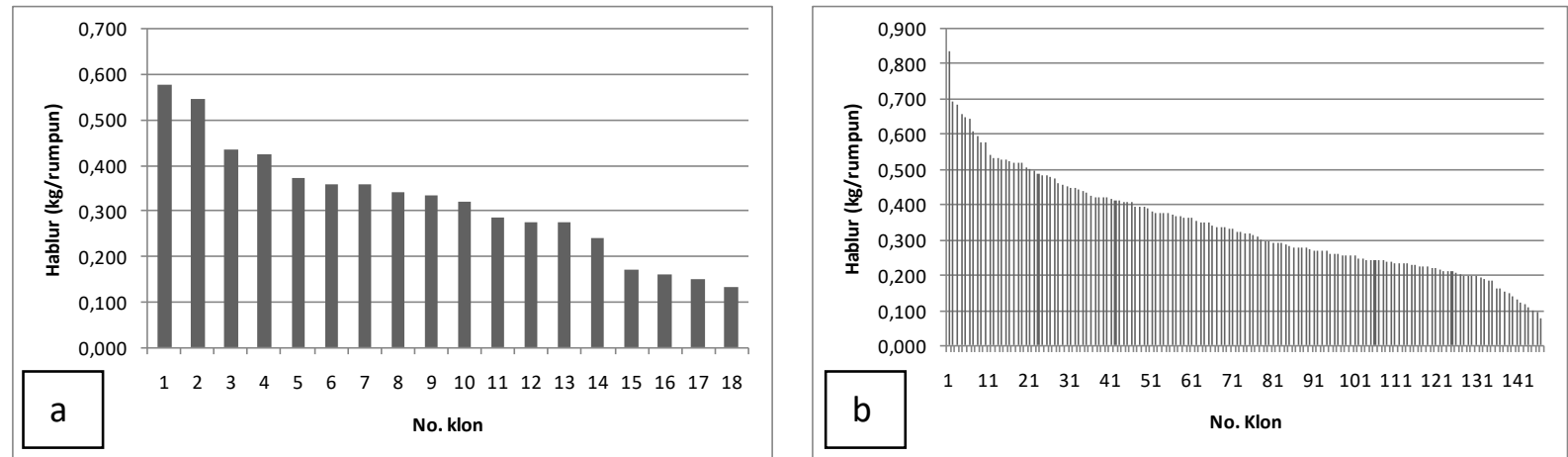

Figure 7 - Crystal yield (a) early-middle ripe sugar cane clones, and (b) middle-slow ripe sugar cane clones

Crystal yield describes amount of sucrose per area (Gomathi et al., 2013). Sugarcane yield and productivity are the two main components contributing crystal productivity (Dashora, 2012 and Junejo et al., 2010). This study showed relationship between crystal yield and yield (Rend) and sugarcane productivity (Protas) and the relationship was shown in an equation, namely Crystal yield $=0.5012$ Rend +0.9226 Protas -0.4077 with coefficient of correlation $(r)$ of 0.992 . It means yield and sugar cane productivity affected $99.2 \%$ of crystal yield. Degrees of influence of sugarcane yield and productivity toward crystal yield were 7.3 and $91.9 \%$, respectively. As a conclusion, method to increase sugar cane yield is to increase productivity. 


\section{CONCLUSION}

Eighteen sugar cane clones indicated as early-middle ripe produced between 1.75 and 6.45 stalks/ cluster or 4.36 stalk/cluster in average. On the other hand, 147 middle-slow ripe clones produced between 2.00 and 7.40 stalks/cluster or in average 4.21 stalks/cluster. Diameter of the early-middle ripe clone stalks is between 1.77 and 3.36 centimeters or 2.57 centimeters in average, while that of the middle-slow ripe clones is between 1.94 and 3.76 centimeters or 2.69 centimeters in average. The early-middle ripe clones are between 88.0 and 207.0 centimeters long (average of 140.61 centimeters), whereas the middle-slow ripe clones are between 48.0 and 199.0 centimeters long (average of 132.1 centimeters).

\section{ACKNOWLEDGMENTS}

The authors would like to thank Head of Indonesian Sweetener and Fiber Crops Research Institute for the 2019 Research Grant. In addition, the authors would also send their gratitude to Dr. Bambang Heliyanto, MSc. and Dr. Djumali, MP for their guidance during the writing process. At last, the authors would like to send their appreciation to the Head and staffs of Kebun Karangploso for their assistance in the completion of this research.

\section{REFERENCES}

1. Chohan, M., U.A. Talpur, S. Junejo, G.S. Unar, R.N. Panhwar, and B. Pa. 2014. Selection and evalution of the diverse sugarcane genotypes in $4^{\text {th }}$ stage. Journal of Animal \& Plant Science, 24 (1), pp. 197-203

2. Dashora, P. 2012. Productivity and sustainability of sugar (Saccharum officinarum) genotypes under planting seasons and fertility levels in south-east Rajasthan. Academia Arena, 4(1), pp. 37-41.

3. Gomathi, R., P.N.G. Rao, D. Rakkyappan, B.P. Sundara, and S. Shiyamala. 2013. Physiological studies on ratoonability of sugarcane varieties under tropical indian condition. American Journal of Plant Science, 4, pp. 274-281.

4. Inoue, K., I. Yamane, T. Kaji. 2009. Effect of nitrogen topdressing and number off tillers at maximum tillering stage on the field and extract quality of ratoon sugarcane cultivar $\mathrm{Ni} 17$. Japanese Journal of Soil Science \& Plant Nutrition, 80(1), pp. 1-6.

5. Islam, M.S., M.A.S. Miah, M.K. Begum, M.R. Alam, and M.S. Arefin. 2011. Growth, yield and juice quality of some selected sugarcane clones under water-logging stress condition. World Journal of Agriculture Sciences, 7(4), pp. 504-11.

6. Jones, M.R., A. Singels, and N.G. Inman-Banber. 2011. Simulating source and sink control of structural growth and development and sugar accumulation in sugarcane. Proceedings of South Africa Sugarcane Technology Association, 84, pp. 157-163.

7. Junejo, S., G.M. Kaloi, R.N. Panhwar, M. Chohan, A.A. Junejo, and A.F. Soomro. 2010. Performance of newly developed sugarcane genotypes for some qualitative an quantitative traits under thatta conditions. Journal of Animal \& Plant Sciences, 20(1), pp. 40-43.

8. Kadarwati, T.F. 2016. Evaluasi kesuburan tanah untuk pertanian tebu di Kabupaten Rembang, Jawa Tengah. J.Littri 22:53-62

9. Khalid, S., F. Munsif, A. Ali, M. Ismail, N. Haq, S. Iqbal, and M. Saeed. 2015. Evaluation of chipbud settling of sugarcane for enhancing yield to various row spacing. International Journal of Agricultural and Environmental Research, 12, pp. 41-48.

10. Kumar, N., H. Singh, R. Kumar, and V.P. Singh. 2012. Productivity and profitability of different genotypes of sugarcane (Saccharum spp) as influenced by fertility levels and planting seasons. Indian Journal of Agronomy, 57 (2), pp. 180-185.

11. Marin, F.R., J.W. Jones, F. Royce, C. Suguitani, J.L. Donzeli, W.J.P. Filho, and D.S.P. Nassif. 2011. Parameterization and evaluation of predictions of DSSAT/CANEGRO for Brazilian sugarcane. Agronomy Journal, 103, pp. 304-315. 
12. Muyassir, Sufardi, I.Saputra.2012. Perubahan sifat fisik inceptisol akibat perbedaan jenis dan dosis pupuk organik. Jurnal Lentera 12:1-8

13. Patel, D., V.C. Raj, B. Tandel, B. Patel, D.U. Patel, and V. Surve. 2014. Influence of planting distance and variety on growth of sugarcane and weed population under mechanization. Journal International of Academic Research For Multidisciplinary. 2(6), pp. 34-41.

14. Rahman, M.A., S.U.K. Eusufzai, S.S. Tabriz, and S.M.I. Hossain. 2008. Optimization of irrigation level for selected sugarcane varieties in AEZ-11 of Bangladesh. The Agriculturists, 6(1\&2), pp. 99-107.

15. Ramadhan,C.I., Taryono,R.Wulandari.2014. Keragaan pertumbuhan dan rendemen lima klon tebu (Saccharum officinarumL.)di tanah Ultisol, Vertisol dan Inceptisol.J.Vegetalika 3:77-87.

16. Sajjad, M., A. Bari, M. Nawaz, and S. Iqbal. 2014. Effect of planting pattern and nutrient management on yield spring planted sugarcane. Sarhad Journal of Agriculture, 30(1), pp. 67-71.

17. Schultz, N., W. Pereira, P.A. Silva, J.I. Boldoni, R.M. Boddey, B.J.R. Alves, S. Urquiaga, and V.M. Reis. 2017. Yield of sugarcane varieties and their sugar quality grown in different soil types and inoculated with a diazotrophic bacteria consortium. Plant Production Science, pp. 1-9.

18. Silva, M.A., J.L. Jifon, C.M. Santos, C.J. Jadoski, and J.A.G. Silva. 2013. Photosynthetic capacity and water use efficiency in sugarcane genotypes subject to water deficit during early growth phase. Brazilian Archives of Biology and Technology, 56(5), pp. 735-748.

19. Soomro, A.F., S. Tunio, F.C. Oad, I. Rajper, M.I. Khuhro, and M.Y. Arain. 2012. Effect of supplemental inorganic NPK and residual organic nutrients on sugarcane ratoon crop. International Journal of Science and Enginnering Research, 3(10), pp. 1-11.

20. Stirbert, A., GY. Riznichenko, AB. Rubin, Govindjee. 2014. Modeling chlorophyll a fluorescence transient: relation to photosynthesis. Biochemistry (Moscow), 79(4), pp. 291-323.

21. Streck, N.A., J.G. Hanauer, L.F. Gabriel, T.C. Buske, J.A. Langner. 2010. Leaf development and growth of selected sugarcane clones in a subtropical environment. Pesquisa Agropecuaria Brasileira, 45(10), pp. 1049-1057.

22. Shukla, S.K. 2007. Growth, yield and quality of high sugarcane (Saccharum officinarum) genotype as influenced due to planting seasons and fertility levels. Journal of Agriculture Sciences, 77(9), pp. 569-573.

23. Tarigan, F.A., J. Ginting, T.E.F. Sitepu. 2015. Respon wadah dan komposisi media pembibitan terhadap pertumbuhan bibit bud chip tebu (Saccharum officinarumL).J. Agroekologi. 3: 458-464.

24. Tyagi, V.K., S. Sharma, and S.B. Bhardwaj. 2013. Pattern of association among cane yield, sugar yield and their components in sugarcane (Saccharum officinarum L.). Journal of Agricultural Research, 50(1), pp. 29-38.

25. Wang, J., S. Nayak, K. Koch, and R. Ming. 2013. Carbon partitioning in sugarcane (Saccharum species). Frontiers in Plant Science, 4(201), pp. 1-6.

26. Yong, Y., S. Gao, Y. Jiang, Z. Lin, J. Luo, M. Li, J. Guo, Y. Su, L. Xu, and Y. Que. 2019. The physiological and agronomic responses to nitrogen dosage in different sugarcane varieties. Front Plant Sciences, 10: 406, pp. 1-18.

27. Zhao, D., B. Glaz, M.S. Irey, C.J Hu. 2015. Sugarcane genotype variation in leaf photosynthesis properties and yield as affected by mill mud application. Agronomy Journal, 107(2), pp. 506-514. 